\title{
VIEWPOINTS
}

\section{The Drawbacks of Judicial Pluralism in the Administration of Justice}

\author{
Ilham Ramli *
}

Legal pluralism in Malaysia has been traditionally a colonial legacy. Legal pluralism not only posits the existence of multiple legal spheres in the same social field but develops certain suppositions concerning the relationships and interaction between them. One area in which there is apparently interesting interaction is in the administration of justice. Whilst legal pluralism may be celebrated because it moves away from the pre-occupation with legal centralism, society cannot afford to have a justice system that is in disarray. This is indeed the case in Malaysia where a common law tradition and civil justice system seem to be at odds with the strong element of religion in the constitution. For more than 50 years, the Malaysian legal system has had to grapple with the ongoing and seemingly endless conflict of judicial authority between the civil and Syariah courts. Syariah courts in Malaysia are exclusively empowered to hear and dispose of cases among Muslims on subject matters enumerated in the first item of List II of the Ninth Schedule of the Federal Constitution. The existence of dual and parallel judicial systems with mutually exclusive jurisdiction in society is in practical terms unsustainable for it essentially creates a crisis of authority. There are two main problems with the current arrangement of dual justice systems in Malaysia; firstly, there is clear infringement of the right to be heard where non-Muslims, who would have a direct interest in the case, are incapable of being heard and have a day in the Syariah courts. Secondly, there cannot be a comprehensive determination of a dispute because of conflicting judicial authorities.

Therefore, there is a need for a minimum commitment to legal centralism by having a streamlined judicial system primarily as a means of securing a functional place for judicial authority that can provide final, timely and comprehensive determination of legal disputes. This presents a two-fold challenge - ideological and institutional - both of which impede the important work of having a reliable and effective administration of justice. Ideologically, a streamlined judicial 
system may be rejected for fear of the subordination of Islamic laws and values to incompatible elements in the civil legal system. While there has been a discussion about certain differences in the underlying values and framework of the civil and religious systems of laws, there is nothing inherently problematic from an Islamic point of view in accepting that civil courts are also Syariah courts. Courts are basically created to administer justice and enforce laws. Although there are bound to be substantive differences between certain aspects and elements of Islamic laws and civil laws, this substantive issue is a matter which is primarily for the legislature to resolve and not the court. Therefore, non-Muslim citizens on the one hand should not worry that they would be arbitrarily subjected to Islamic laws. On the other hand, Muslims should embrace the fact that the status and identity of Syariah courts are never contingent upon the name or the fact that they are independently separated from the civil courts.

The success of Islamic finance illustrates that there is no ideological hurdle making it impossible for Islamic law to be administered by the civil courts. Islamic law in a modern form will go through the democratic legislative process at the legislative assembly whereby Syariah rules from the whole corpus of Islamic teachings are extracted and crystalised into a set of legislations by Parliamentarians. Islamic finance instruments which are substantively governed, among other things by the Syariah law can be administered sequentially notwithstanding some views to the contrary by the civil courts. It indicates that there is actually no real distinctive impediment - ideological or jurisprudential to treating Islamic laws and civil laws alike in the context of the administration of justice.

It may be contended, however, that the example of Islamic finance is inadequate because, in a secular system, most if not all of its facets can be adopted under the concept of private autonomy of contract. Rather, the plausibility of having a streamlined judicial system should be considered in the contentious areas of family and inheritance law, personal status law, criminal law, gender inequality, and human rights in general, in order to map out how an incorporation of Syariah into the civil court system would work. It is actually not difficult for a streamlined judicial system to work even in these contentious areas if we jurisprudentially rely on the legal positivism school of thought. Legal positivists maintain that the validity of law derives from its source. Therefore, ordinary courts can administer any law passed by the legislative assembly regardless of its pith and substance, which may be religious in nature. Any disagreement on the scope, propriety and applicability of highly contentious norms which may have strong religious elements has to be sorted out by Parliament. On this score, Islamic law will be administered and treated equally in comparison to any other branch of law; tort, contract law, criminal law, defamation law etc. Equal treatment here refers to 
the ideal situation where all laws are administered by a single judicial authority within a broad single judicial framework. As such, there will be no issue about court jurisdiction to adjudicate a legal dispute.

Institutionally, the dual and parallel judicial systems in Malaysia are purportedly designed to serve the interests of both Muslims and non-Muslims. It was thought that the arrangement would be capable of safeguarding the nonMuslims from being subjected to Islamic laws whilst at the same time giving space for the Muslim community to practice its personal laws. But in practice, the current arrangement means there is no single judicial authority that would have jurisdiction over all subjects. It is an intricate challenge to resolve a dispute when there are two judicial bodies claiming authority over the same matter.

The issue of a dual judicial system with parallel jurisdiction is an institutional problem and must be addressed structurally. It is also a constitutional problem that cannot be completely addressed with piecemeal solutions using various canons of construction or technical legal interpretation of constitutional provisions, for these would not solve the core issue of conflicting authority. Courts are established to adjudicate legal disputes, and this judicial role is primarily a norm-applying function. Therefore, for the sake of finality, consistency and predictability, courts in Malaysia should be streamlined into one system and vested with jurisdiction over all members of society. This suggestion acknowledges that there can be different kinds and levels of courts as the state deems fit. The Syariah principle of particularisation of justice (takhsis al-qada) also permits the setting up of specialised courts. This multiplicity should not in any way be mistakenly understood to imply the existence of multiple judicial authorities for there is actually only one judicial authority, which is essentially monolithic and indivisible.

It does not follow from the proposal of a streamlined judicial system, however, that certain segments of society cannot be exempted from the application of certain specific laws. The inapplicability of Islamic laws to non-Muslims is an accepted Syariah position and can still be retained. Instead of protecting nonMuslims by creating two different courts, civil and Syariah, non-Muslims may be statutorily exempted from certain specific areas of law. This is in line with the doctrine of reasonable classification that permits differentiation based on an intelligible differentia. In the context of the criminal justice system, for example, an Act of Parliament may criminalise adultery and provide a punishment for such an offence that is applicable to Muslims only. In this way, the clash of judicial authority would not arise because there is only one authority that exists to administer different kinds of law on all citizens.

The inapplicability of certain Islamic laws to non-Muslims is also feasible in light of the prerogative of the Public Prosecutor to choose the most appropriate 
charge in criminal cases. The prerogative of the Public Prosecutor to choose an offence that carries a higher punishment against the accused person over the same facts is common. In Malaysia, a suspect who has been apprehended by the authorities for unlawful possession of firearms, for example, can be charged under Section 8 of the Arms Act 1960, and shall, on conviction, be liable in respect of such contravention to imprisonment for a term not exceeding seven years, or to a fine not exceeding ten thousand ringgit, or to both. Alternatively, the suspect may be charged under Section 8 of the Firearms (Increased Penalty) Act 1971, and shall, on conviction, be punished with imprisonment for a term which may extend to fourteen years and with whipping with not less than six strokes.

In the context of a streamlined judicial system, the scepticism of those who reject the consolidation of civil and Syariah courts on the grounds that such consolidation amounts to 'secularisation' of the religious court does not hold water because an acceptable degree of exclusivity and autonomy of Syariah law is still maintained in the system. The Public Prosecutor, for example, would have the option whether to charge a Muslim suspect for the offence of stealing under the Syariah Penal Code (punishable with amputation of the hand) or under the ordinary Penal Code (punishable by imprisonment). The decision can be made upon considering the whole facts and context of a case to ensure the requirements of legality, propriety and proportionality are adequately met.

Ultimately, we have to get out of this binary dichotomy of civil and Syariah courts in the cause of a better Malaysia. Maintaining such a dichotomy will not serve any good purpose because a decentralised judicial system is an injustice in itself. The need to have a streamlined judicial system should be our priority, particularly for those who are serious about uplifting the current status of the Syariah Courts. This can be done by dispensing with the unnecessary and selfdefeating separation between the Syariah courts and the civil courts. As such, the Syariah courts are recognised as specialised courts in the whole scheme of the judicial system. Alternatively, if the current arrangement were to be retained then non-Muslims, at the very least, must be allowed to appear and bring cases before the Syariah courts. It is a pure injustice if citizens are restricted from appearing before any court of law simply on the ground of their religion.

* Ilham Ramli is a Research Fellow at the International Institute of Advanced Islamic Studies (IAIS) Malaysia. He can be contacted at ilham@iais.org.my. 